\title{
The Political and Moral Economies of Neoliberalism: Mises and Hayek
}

\author{
João Rodrigues *
}

\begin{abstract}
This article compares the political and moral economies of Ludwig von Mises and Friedrich Hayek. It argues that some of the relatively less scrutinised intellectual divergences are located in their views on the roles of the state within a market society. Convergences will also be identified, particularly in the field of moral economy, where despite their different positions on rationalism and utilitarianism, one can find a fundamental agreement on the positive causal effects of certain economic institutions on values. This is accompanied by a sceptical view on the future of market society related to the ongoing strength of institutions fostering ideologies inimical to markets, which is one of the factors explaining the importance both gave to the battle of ideas and to the corresponding effort to deliberately shape public opinion.
\end{abstract}

Key words: Mises, Hayek, Neo-liberalism, Politics, Morality

FEL classifications: B25, B53, P10

\section{Introduction}

This article compares the political and moral economies of Ludwig von Mises and Friedrich Hayek, the two most important Austrian economists in the twentieth century. It moves beyond the differences in the calculation versus the knowledge arguments against socialism within the socialist calculation debate put forward by Mises and Hayek, respectively, which have been thoroughly researched and debated.

It argues that some of the relatively less scrutinised intellectual divergences are located in their views on the roles of the state within a market society and on the definition of the political conditions that are necessary to ensure the viability of that kind of society. This might help shed new light on the main intellectual sources of Hayek's pragmatic stance and Mises's uncompromising position towards the lines that would have to be drawn between states and markets (Peck, 2008).

Convergences can also be identified, particularly in the field of moral economy, where despite their different positions on rationalism and utilitarianism, one can find a fundamental agreement on the positive causal effects of certain economic institutions

Manuscript received 21 April 2011; final version received 15 February 2012.

Address for correspondence: Colégio S. Jerónimo, Apartado 3087, 3001-401, Coimbra, Portugal; email: joaorodrigues@ces.uc.pt.

${ }^{\star}$ Centre for Social Studies, University of Coimbra. The author acknowledges the financial support of Fundação para a Ciência e Tecnologia (SHRH/BD/38310/2007 and SFRH/BPD/74209/2010). I thank John O’Neill, John Salter, Ana Santos, José Maria Castro Caldas and two anonymous referees for the critiques and suggestions that significantly improved this article. All errors and omissions are of my own making.

C The Author 2013. Published by Oxford University Press on behalf of the Cambridge Political Economy Society. All rights reserved. 
on values. Both Mises and Hayek consider that institutions of a commercial kind nurture individuals' most adequate and functional motivations. This position is nevertheless accompanied by a sceptical view on the future of market society related to the ongoing strength of institutions fostering atavistic attitudes and ideologies inimical to markets, which is one of the factors explaining the importance both give to the battle of ideas, ideological hegemony and the corresponding effort to deliberately shaping public opinion and reconfiguring the state.

Indeed, the foundation of the Mont Pelerin Society in 1947 epitomises the recognition that ideas are the crucial element in the evolution of social order. This is the defining moment of the emergence of 'organised neoliberalism' as a post-war intellectual and political trend (Plehwe, 2009, p. 5). The Mont Pelerin Society was mainly the result of Hayek's initiative and counted with the participation of Mises amongst a host of intellectuals coming from different countries and disciplinary backgrounds. Nevertheless, there was a clear dominance of economists from the United States and Western Europe.

Amongst the themes mentioned in the draft of the statement of the society's aims, three issues (to be tackled in this article) clearly emerge as the intellectual priorities of this community: 'The precise character of the legal and institutional framework within which competition will work most effectively and which will supplement the working of competition', that is, the institutional and legal foundations of the market sphere and of the associated non-market spheres; the idea that 'any free society presupposes, in particular, a widely accepted moral code', that is, the relationship between morality and capitalism; and the diagnosis that 'the changes in current opinion which are responsible for the general trend toward totalitarianism are not confined to economic doctrines', expressing the shared conviction that trends in the realm of ideas, broadly conceived, could go a long way in explaining developments in political affairs (Hartwell, 1995, pp. 49-50). ${ }^{1}$ Being contentious issues amongst the participants of the Mont Pelerin Society, which demarcated the different intellectual currents-from German ordo-liberalism to the Chicago school and to Austrian economics-loosely coalescing in neo-liberalism, these are also questions about which Mises and Hayek, generally grouped in a monolithic and extreme wing of the movement, had both agreements and disagreements that deserve further scrutiny. This scrutiny allows us to further problematise neo-liberalism as a much more heterogeneous ideological movement, whose vitality can also be found in the different contributions of its intellectuals leaders.

\section{The political economy of neo-liberalism: Hayek versus Mises?}

Hayek's remarks, from the 1930s onwards, about the insufficiency of the slogans of laissez-faire and his pleas for a more sophisticated and open attitude towards the state and the institutional underpinnings of capitalism could have had Mises's work (amongst others') in mind. Hayek's (1948, pp. 110-11) 'Free Enterprise and Competitive Order', presented at the inaugural meeting of the Mont Pelerin Society, seems to be a good example of this critical exercise:

That a functioning market presupposes not only the prevention of violence and fraud but also the protection of certain rights, such as property and the enforcement of contracts, is always

\footnotetext{
${ }^{1}$ Although this draft was never made public, given the lack of agreement amongst the participants in the meeting, the themes mentioned here are present, albeit in a more diluted form, in the final statement of aims of the society (Plehwe, 2009, pp. 22-24).
} 
taken for granted. Where the traditional discussion becomes so unsatisfactory is where it is suggested that, with the recognition of the principles of private property and freedom of contract, which indeed every liberal must recognize, all issues are settled, as if the law of property and contract were given once and for all in its final and most appropriate form. ... It is only after we have agreed on these principles that the real problem begins.

This is an elaboration of a general diagnosis, already present in the idea that liberal economists had neglected the inquiry into the positive roles that the state might have (Hayek, 1933). In The Road to Serfdom he details the insufficiencies and even the perversities of the "wooden insistence of some liberals on some rough rules of thumb, above all the principles of laissez-faire" (Hayek, 1944, p. 18). The role of the state, of course, is one of the areas in which this insistence was particularly visible, demanding a change in the terms of the debate within economic liberalism: 'The question whether the state should or should not "act" or "interfere" poses an altogether false alternative, and the term laissez-faire is a highly ambiguous and misleading description of the principles on which a liberal policy is based' (Hayek, 1944, p. 84). Hayek's rejection of laissez-faire is part of a previous and wider intellectual trend, well expressed by Keynes's the 'end of laissez-faire' published in the 1920s. Hayek tried precisely to differentiate liberalism from laissez-faire. ${ }^{2}$ The Colloque Walter Lippman, held in Paris in 1938 and considered an antecedent of the Mont Pelerin Society, is also a collective expression of this endeavour. It was there that the term neo-liberalism was first used (Audier, 2008).

The thesis advanced here-that these remarks can be seen as an implicit critique of Mises's political economy - can only be sustained if one bears in mind the latter's very general and principled remarks about the 'minimal state' as the guarantor of the political conditions for private property and the 'unhampered market', forming the broad institutional pre-conditions for a rational capitalist economy (Mises, 1949). ${ }^{3}$ Hayek accepts the validity of these remarks. Nevertheless, from the foregoing quotations one can identify the main components of what would constitute an important departure: although Hayek (1944) thought that Mises was fundamentally correct in his position that barbarism was the only alternative to capitalism (Gamble, 1985), his account was considered simultaneously too general and too intransigent to be the last word on the subject. In fact, it was incapable of properly facing the 'real problem': the intellectual and political challenges facing economic liberalism that would lead to its progressive transformation into neo-liberalism. 'Planning for freedom' or 'planning for competition', expressions that he uses in Freedom and the Economic System and in The Road to Serfdom, meant the deliberate assurance of the institutional underpinnings of a permanently evolving market order (Hayek, 1939, 1944).

Hayek, then, sets a more challenging intellectual task for the members of the Mont Pelerin Society and for himself. At least three related reasons can be identified. First, Hayek recognised the need, and perhaps the unavoidability, of a more ample role for the state in capitalism than Mises was willing to concede. Hayek identified a host of

\footnotetext{
${ }^{2}$ I thank an anonymous referee for having drawn my attention to this.

3 Mises defended a utilitarian approach to the issues at stake. He had a strong conviction that the debates in comparative political economy could be clearly settled in favour of laissez-faire capitalism and that this system and the morals sustaining it were the only bulwarks against the destruction of civilisation. His approach can easily be reinterpreted as an intransigent defence of certain principles, more akin to the natural rights tradition on which libertarianism is based. See Eshelman (1993) for a re-interpretation along these lines. Nevertheless, as the author reluctantly recognises, Mises's arguments in favour of liberalism are always couched in clear utilitarian terms.
} 
goods and inter-dependencies whose importance was unceasingly increasing due to industrialisation and urbanisation and that the market was unable to deliver and manage, at least not without the support of non-market institutions. This might explain why Hayek (1960, p. 194) significantly considers, in a continuation of his efforts to go beyond liberal generalities about economic freedom as mere absence of state interference, that: 'It is the character rather than the volume of government activity that is important. A functioning market presupposes certain activities on the part of the state; there are some other such activities by which its functioning will be assisted; and it can tolerate many more, provided that they are of the kind which are compatible with a functioning market'. Second, Hayek was aware of what Unger (1998) much later called the trap of 'institutional fetishism'. This leads many, including Mises, to be convinced that abstract institutional conceptions such as the market economy have necessary and immediately obvious concrete institutional expressions. This conviction thus evades the need to think about how the problem of the 'legal indeterminacy' of such abstract conceptions might be solved through an always contestable and precarious allocation of legal rights and obligations to different agents (Unger, 1998). Third, one of Hayek's greatest contributions to social theory - the recognition of the dissemination and imperfection of all knowledge-precludes the kind of social rationalism to which Mises explicitly adhered and which allowed him to draw such apparently clear and definitive boundaries between the state and the market. ${ }^{4}$ The least scrutinised differences, and perhaps the most important ones, between Mises and Hayek are located in the implications they drew from their comparative institutional exercises to the conditions for the viability of the capitalist system. This point can be better grasped by first summarising Mises's main tenets in this regard.

\section{Drawing clear lines between state and market}

Mises (1949, p. 257) defines the market economy, which he always equates with laissez-faire capitalism, as 'the social system of the division of labour under private ownership of the means of production'. Private ownership is at the root of his thin institutionalist conception of the unhampered market (Keizer, 2000). Private property, and 'not a certain misunderstood notion of free competition', which had to be politically guaranteed, for example through robust anti-trust laws, constitutes the core of his 'classical liberalism' (Mises, 1929, p. 18). The market is characterised as a catallaxy, a

\footnotetext{
${ }^{4}$ This contribution started as part of a research agenda against socialism. Hayek was of course aware that Mises's anti-socialist work was 'the starting-point from which all the discussions of the economic problems of socialism, whether constructive or critical, which aspire to be taken seriously must necessarily proceed' (Hayek, 1935, p. 33). Nevertheless, there are two crucial moves that distance Hayek from Mises already in the socialist calculation debate. The first is methodological: Hayek (1937) rejected the pure logic of choice, the basis of Mises's aprioristic form of reasoning about economic affairs, and argued that understanding how economic agents learn implied giving an account of the actual division of labour and knowledge in society and the process agents would find to make their plans compatible. This implied acknowledging the empirical dimension of economics (Caldwell, 2004). The second move is both epistemological and institutional. Hayek realised that the conception of rationality in economics was too demanding and its dependence on the institutional configuration of the economy too under-scrutinised. Therefore, his critique of socialism became simultaneously a critique of 'rationalism', of the idea that individuals could through a means-ends framework clearly appraise their economic alternatives and the effects of the particular and clearly designed institutions. Furthermore, the limited, tacit and incommensurable nature of much of the knowledge possessed by market participants meant that rationality was not only more fragile but fundamentally dependent on the rules that were in place.
} 
process of rivalry amongst private agents who are assumed to have full control of the factors of production, whether they be labour, capital or land. ${ }^{5}$ The existence of 'free markets' depends on the existence of 'full private property rights', necessarily bundling the three property rights usually referred to as control, cash flow and alienation rights: 'get your property institutions right!' and ensure their integrity are Mises's main messages and tasks for policy makers (Keizer, 2000, p. 319). This is, then, the sole political pre-condition for what he considered to be, almost by definition, uncoerced exchanges based on and giving rise to genuine prices, that is, capitalist prices reflecting relative scarcities as viewed by the subjective evaluations of the participants.

The existence of a real market sphere, which exactly coincides with the sphere where individuals can make meaningful monetary cost-benefit calculations, necessarily has to rely on the existence of a bureaucratic sphere governed by other considerations: 'There are areas of man's activity in which there cannot be any question of profit management and where bureaucratic management must prevail' (Mises, 1944, p. v). For Mises, the sphere of the state exactly overlaps the sphere of bureaucratic management: 'the method applied in the conduct of administrative affairs the result of which has no cash value on the market' and which 'cannot be checked by economic calculation' (Mises, 1944, pp. 49-50). This sphere must be reduced to the task of ensuring the integrity of the market mechanism, which is seen as a simple task if liberal principles are not diluted by compromises with all sorts of 'interventionist' ideologies.

There is an institutional and behavioral dichotomy at the root of Mises's economic liberalism. The sphere of the market favours an entrepreneurial behaviour motivated 'solely by the selfish interest in making profits and in acquiring wealth' (Mises, 1949, p. 288). This behaviour involves valuable entrepreneurial dispositions that are fostered by the particular position held by certain individuals in the capitalist production process (Mises, 1922, 1949). Indeed, the interactions fostered by the process of market exchange tend to be 'dictated by selfishness on either side' (Mises, 1949, p. 283). At the heart of Mises's (1920) argument, at least from his first intervention in the socialist calculation debate, there is the idea of a commodification-commensurability nexus, which is specific to capitalism and allows for the emergence of a particular form of rationality - the 'algorithmic conception of rationality' (O'Neill, 1998). The market sphere is the space where a conception of rationality based on economic calculation implying commensurability amongst goods, that is, their reduction to a single metric, suffices. This space can progressively gain ground if the deliberate 'expansion of the scope of things which are negotiated on markets against money' becomes the main goal of public policy (Mises, 1949, p. 230). This expansion depends on what happens in the other relevant sphere, that of the 'minimal state', which is antecedent to the sphere of the market and has to rely on rule-following behaviour. Although essential for the functioning of the state apparatus, given the absence of the monetary yardstick, rule-following behaviour precludes innovation and entrepreneurship. The state relies on a 'non-algorithmic conception of rationality' (Greenwood, 2006), on particular moral and ideological conceptions that have to be accepted by the citizenry in general and state officials in particular. Therefore, the state can be kept in its place only if

\footnotetext{
5 The concept of rivalry in Austrian economics is, as Lavoie (1985) has argued, fundamentally different from the idea of perfect competition dominant within neo-classical economics, being intrinsically linked with a particular set of institutions and patterns of behaviour, which the state or other organisations cannot mimic, and in a context of uncertainty in which the future is not a mere statistical shadow of the past.
} 
certain ideas become pervasive through the ultimately benevolent efforts of a minority of bureaucrats and intellectuals that forge them.

Thus, there is a neat division between the sphere where economic calculation is possible and the sphere where it is impossible, coupled with the conviction that the state initiatives-'measures that are taken for the purpose of preserving the private property order are not interventions' (Mises, 1929, p. 17) — can be easily defined, circumscribed and distinguished from 'interventionism', which is considered to be unavoidably counter-productive. This division gives Mises's efforts at drawing the line an apparent clarity and certainty, regardless of their political implausibility in the face of the available record of the growth and stability of the so-called mixed economy in the twentieth century, as recognised even by those who work in the Austrian tradition (Ikeda, 1997).

Mises's confidence ultimately derived from social rationalism, the claim that 'the complex of human social relations is, in a fundamental sense, the product of rational design' (Salerno, 1990, p. 49). This rational design was not only possible from an epistemological point of view but also unavoidable in the face of the existence of a host of alternative designs put forward by different political and intellectual groups. In Mises's work, the possibility of rational design is anchored in utilitarianism. This gives individuals a clear yardstick with which to appraise their individual acts and also appraise the social rules that frame them, thereby constituting the indispensable philosophical tool for his 'liberal' political and moral economy. The plausibility of this yardstick, operating at the individual and social levels, is crucially related to two ideas. First, individuals are above all 'motivated by the urge to improve the material conditions of their existence', which means that all relevant policy discussions can be reduced to this single and deceptively simple issue (Mises, 1949, p. 193). Second, the expansion of a relatively unspecified 'unhampered market' is what allows the progressive achievement of this goal, matching better than any other available process individuals' 'true interests' and the necessary rules that underpin social order.

The possibility of market failures, as conceived in several traditions in economics, is refused. For Mises the market has, to borrow Kirzner's (2000) terms, no 'inner limits', only 'outer limits', that is, necessary legal arrangements to be provided by the state, and necessary 'shared ethical principles' that are said to coincide with the interests of egotistical individuals enlightened by appropriate principles. The market thus understood is the sole public good that the state has to guarantee by ensuring its integrity-thus helping achieve the ideal of a 'pure market economy' (Mises, 1949, p. 239) —and the main task of intellectuals is to convince people that this is indeed the case. Only in this context can one understand Mises's repeated presentation of the issues at stake in the debates in terms of stark social choices and predictions: 'Men must choose between the market economy and socialism. They cannot evade deciding between these alternatives by adopting a "middle-of-the-road" position, whatever name they may give to it' (Mises, 1949, p. 861).

\section{Blurring the lines}

Hayek shares with Mises the conviction that stark choices cannot be avoided. The idea of a mixed economy, combining elements from capitalism and socialism, is considered an inefficient and politically unstable 'muddle' that tends to degenerate into a more inefficient and politically authoritarian solution, as the basis of the 'Great Society', the market system, is progressively impaired. Hayek (1979, p. 112) credits Mises (1949) 
with having revived the 'appropriate term', catallactics, to refer to the science that studies the complex market order - the catallaxy - that is, a social order whose structure is fundamentally given by the 'disdained "cash-nexus"'. In a sense, both authors converge in the liberal assumption, as identified by Polanyi (1944), that the possibility of a market society, where economic relations are essentially guided by selfish responses to market prices, is dependent on the subordination of the political sphere to the tasks of preserving the integrity of the market sphere. This, in turn, implies that its functioning be guided by criteria different from those of the market. This is explicitly stated by Hayek (1979, p. 65), approvingly quoting Mises (1949): 'the pure market economy assumes that government, the social apparatus of compulsion and coercion, is intent on preserving the operations of the market system'.

The divergence between the two starts in the definition of what these tasks are, with Hayek much closer than Mises to Polanyi's (1944) characterisation of the paradoxical relation between the state and markets in capitalism: the development of markets demands an expanding state with the power to impose the rules that markets require.

This was one of the most 'implacable antinomies' that neo-liberalism, as spearheaded by the Mont Pelerin Society, had to face before and after its ideological affirmation: 'a primary ambition of the neoliberal project' was to operate a reconfiguration of the shape and functions of the state, once it was realised that a 'strong state' was needed to guarantee the spreading of market relations (Mirowski, 2009, p. 436). Hayek's work is thus marked by a greater willingness to face this antinomy and think anew about how to set the boundaries of this enlarged state and also about the limits of the market relations it was supposed to nurture. Hayek went well beyond and even against Mises. This important rupture is already hinted at in his critiques of the simple rules of thumb and harmonies of laissez-faire, as expressed by Mises's defence that 'under laissez-faire capitalism different persons' interests do not truly conflict' (Oliver, 1960, p. 282).

The outer limits of the market were scrutinised by Hayek in a way that led to the conclusion that the institutional underpinnings of capitalism are always more plastic, malleable and difficult to define than Mises was willing to acknowledge. This also led to the recognition (much less noticed) that the market has inner limits, that is, that market failures, from externalities to public goods, do exist: 'We must, of course, not forget that there are in a modern community a considerable number of services which are needed . . . and which could not be possibly be provided by the market for the obvious reason that no price can be charged to the beneficiaries or, rather, that it is not possible to confine the benefits to those who are willing or able to pay for them' (Hayek, 1948, p. 111). There could be diverse state-sponsored solutions intended to make private agents recognise the social costs or social benefits of some of their activities and incorporate these costs and benefits in their market decisions. ${ }^{6}$ The examples Hayek alludes to also tend to repeat themselves: 'such are most sanitary and health services, often the construction and maintenance of roads, and many of the amenities provided by municipalities for the inhabitants of cities' (Hayek, 1960, p. 196). Hayek admits that it is impossible to draw a clear-cut line between private and public goods.

The distinction is never very easy to draw also because some of the corrections proposed by Hayek for market failures are conceived of as part of the political travails of ensuring the malleable institutional underpinnings of a functioning market society:

\footnotetext{
${ }^{6}$ See Rodrigues (2010) for a more developed account of this theme.
} 
'the functioning of competition not only requires adequate organization of certain institutions like money, markets, and channels of information-some of which can never be adequately provided by private enterprise-but it depends above all on the existence of an appropriate legal system', which has to be 'intelligently designed and continuously adjusted' (Hayek, 1944, pp. 39-40).

Other aids to a functioning market society, such as Hayek's repeated defence of a minimum income to be guaranteed by government to those incapable of taking part in market relations, are grounded in a pragmatic recognition that the political legitimacy of the catallaxy is frail. It might be menaced by the myopic action of the individuals temporarily or, perhaps less frequently, permanently excluded from its benefits.

This position tends to be considered unprincipled by friends and foes alike. Block (1996) presents it as an example of a host of 'interventionist concessions' made by Hayek to his opponents. Mises, on the other hand, is praised by Block (1996) for always refusing them. It is true that this concession further reveals the different understanding Mises and Hayek had of the tasks of government and the virtues of the market, presenting an additional argument for the thesis that Hayek was willing to face the growing complexity of the tasks of the state within a developing market society. Burczak (2006, p. 92), on the other hand, thinks that the unavoidable redistributive bent of this government-sponsored guaranteed income does not fit well with 'a framework that elevates equality under the law as the guiding normative principle for modern society'. If one is aware that the latter was established by Hayek (1960) to generate principled lines between the agenda and non-agenda of government within liberalism, then this is a problematic critique. Hayek's rule of law is of such a nature as to be explicitly compatible with a principle of expediency that allows this and many other activities of the so-called service state, conceived as a 'piece of utilitarian machinery' (Hayek, 1944, p. 80).

Contrary to the interpretation, systematised by McCann (2004), Hayek is not as anti-utilitarian as it may seem. There is what can be labelled as a circumscribed utilitarian moment in his thought, contrasting with Mises's more unconstrained adherence to a utilitarian position. Hayek's position is not without its problems, but it seems compatible with his strictures about the limitations and possibilities of human knowledge. Hayek (1979, p. 205) criticises Mises for being 'a rationalist utilitarian' when the latter considers that all human actions and rules could be seen as aimed at achieving the maximum utility possible. For Hayek (1976), act-utilitarianism assumes that individuals are endowed with an implausible intellectual omniscience that would, if true, turn all sorts of rules, legal and moral, irrelevant. These rules, if well defined and structured, are the essential aid for necessarily fallible individuals, who possess limited amounts of knowledge about the consequences of their actions and unavoidably have their means and ends partially shaped by the institutional milieu in which they interact (Hayek, 1960). Good rules serve to reduce uncertainty and ignorance by roughly indicating what individuals can expect from others and what others can expect from them, while allowing them to adapt to new circumstances and providing the opportunity to take part in unforeseeable new events (Hayek, 1960, p. 28). Contrary to rule-utilitarianism, Hayek (1976) considers that the nature of social life precludes the appraisal of the utility of each rule because this is dependent on the functioning of a wider set of rules. The 'telic justification' of a complex system of rules minimising coercion and maximising freedom, which according to Mack (2006, p. 277) is at the root of Hayek's thought, is based 'on the belief that it will, on balance, release more forces for the good than for 
the bad' (Hayek, 1960, p. 28). But this view is ultimately non-utilitarian. Once one grasps the nature and limits of existing knowledge, and the institutions that best ensure the unfolding of a valuable process of discovery, one is led to the conclusion that the utilitarian project is bound to fail, mainly for epistemic reasons. Hayek concludes that the progress of the catallaxy should not be stopped and should be seen without any conservative apprehension because ultimately, 'progress is movement for movement's sake, for it is in the process of learning, and in the effects of having learned something new, that man enjoys the gift of his intelligence' (Hayek, 1960, p. 38).

There is still scope for the utilitarian yardstick, although a more limited one. Hayek (1960) considers that the usefulness of state activities, for which there is ample room within the strictures of the rule of law (particularly in the area of regulation of markets and in the correction of their various failures, as in the provision of some forms of expert knowledge that market participants need), can be appraised by a utilitarian evaluation of the net benefits of these interventions. However, the way the benefits and costs are measured is left unspecified. Recourse to the principle of expediency can be seen as a way of trying to depoliticise what are in reality eminently political decisions. Its logic can be found in Hayek's distinction between made orders, also called organisations, which are driven by shared ends, and the wider spontaneous order, or catallaxy, made of market exchanges where there cannot be shared ends, including that of maximising social utility, because the process of adjustment and coordination is said to be only 'means-connected' (Hayek, 1979). The state, given the monopoly of coercion it possesses, is a particular organisation with a crucial role in the 'cultivation' of the market order. This role can be appraised within a means-ends framework of a utilitarian bent, but this is precluded in the wider spontaneous order.

Perhaps Hayek's well-known insistence on the limits of reason and knowledge and his critiques of the rationalist undertone of Mises's wider utilitarianism have contributed to creating a seeming paradox that has gone unnoticed in the secondary literature: Hayek's supposedly anti-rationalist contribution to the theory of knowledge delimits the application of the utilitarian yardstick solely to the realm of the state, which is an organisation with comparatively well-defined ends and means; at the same time, he proposes a much more demanding agenda for the political engineering of markets than Mises's rationalism is willing to recognise, including a role in the gathering of valuable knowledge. ${ }^{7}$ As Greenwood (2007, p. 428) has recently emphasised, 'Hayek does not entirely reject the possibility of centralized institutions having access to economically relevant knowledge'. For example, in discussing the exploitation of natural resources, Hayek (1960, p. 321) claims that:

It cannot be denied that there are some facts concerning probable developments which the government is more likely to know than most of the individual owners of natural resources. Many of the recent achievements of science illustrate this.... We can bring together all the knowledge

\footnotetext{
7 The use of the expression 'political engineering' as a characterisation of Hayek's thought in this regard goes against his reluctance even to adopt Popper's conception of 'piecemeal engineering' associated with 'the method of searching for, and fighting against, the greatest and most urgent evil of society' (Popper, 1945, p. 148): it 'suggests to me too much of a technological problem of reconstruction on the basis of the total knowledge of the physical data' (Hayek, 1976, p. 157). Nevertheless, Hayek is not only in agreement with the substance of what Popper intended by the term - 'we can always tinker with parts of a given whole but never entirely redesign it' (Hayek, 1976, p. 25) - but in his actual appeals and proposals towards the neoliberal reform of capitalism, Hayek was always willing to appeal to the possibility of using the power of the state, given the knowledge available about the relative merits of different institutional arrangements, to effect a change in the socio-economic trajectory (Gray, 1998; Shearmur, 2006).
} 
that is relevant to particular problems only by dispersing downward the generic knowledge available to government, not by centralizing all the special knowledge possessed by individuals.

Hayek's recognition of diverse forms of knowledge allows for the existence of an institutional framework where a plurality of devices, market and non-market, are needed. They ensure that these different forms of knowledge are generated, protected and diffused. The Hayekian need to 'plan for competition' means that in the end, he shared Mises's concerns about guaranteeing the integrity and expansion of markets, as the irreplaceable framework for a progressive society, while realising that this was a much more demanding and uncertain political task. The subordination of the non-market sphere to the diverse and complex requirements of the market sphere was not as easy to specify in advance as Mises thought it was by distinguishing between the sphere of economic calculation and the sphere of the minimal state where economic calculation is not possible.

Once the problem of the political legitimacy of markets and their institutional and legal malleability and the incapacity of economic actors spontaneously to acknowledge the social costs and benefits of their economic activities are recognised, given the existence of externalities and public goods, the scope of state activities automatically increases. The lines between markets and the state become more blurred and difficult to define.

Hayek was willing to go beyond the minimal role of the state, having as its sole task the monopoly of coercion, indispensable to defining and protecting property rights and contracts. He added one important caveat: that the state should never exercise a coercive monopoly in the provision of whatever additional goods and services it thought useful to provide through public financing. Hayek was an important proponent of one of the most important neo-liberal ideas: the activities of the so-called service state, contrary to Mises, could be the targets of a deliberate process of what Marquand (2004) called 'market mimicry' incorporating at least some features of market competition. ${ }^{8}$

Having scrutinised the major intellectual differences of the political economy of Hayek and Mises, one is in a better position to understand that the central aims of neoliberalism - discovering the best ways to ensure flourishing markets through a redefinition of the realm of legitimate state activities-was as complex as it was contentious, even amongst two leading authors of Austrian economics, generally considered to be the most intransigent and monolithic branch of neo-liberal political economy.

\section{The moral economy of neo-liberalism: Mises and Hayek}

It is also possible to identify a common willingness to delve into the relationship between institutions and individuals' motivations and character - the agenda of moral economy, whose neo-liberal version argues for the idea that a market society needs a widely shared moral code, albeit a relatively thin one, while tending to be a force for its promotion. This grounds and gives coherence to their effort to think about and intervene in the development and evolution of ideas, which would ultimately decide how individuals thought about their interests and influenced how the fundamental institutions of society would evolve.

In both Mises and Hayek, one can find an argument for 'endogenous preferences' (Bowles, 1998), a crucial part of their moral economy, fitting into Hirschman's (1982) thesis, taken from Montesquieu, of the doux-commerce, albeit with some differences

${ }^{8}$ Hayek's (1960) defence of Friedman's idea of school vouchers is a case in point. 
in emphasis between them. These differences are particularly visible in the potency of the presumed positive effects of markets on individuals' character and rationality. For Mises (1922), human rationality was partially an outgrowth of the practice of economic calculation, which is only possible in markets - a process that is grasped once the 'inner and necessary connection between the evolution of the mind and evolution of society' is acknowledged (Mises, 1922, p. 266). 'Free markets' are the main generators of human sociality, economising on morality because (Mises repeatedly stresses this point) individuals' selfish motivations tend to transmute into desirable social results. At the same time, markets internally produce the moral norms that are needed to economise on the state 'apparatus of compulsion and coercion', by making 'friends out of enemies, peace out of war, society out of individuals' (Mises, 1949, p. 163).

The presumed nature of the patterns of interaction favoured by markets is expressed by these two effects, ultimately leading Mises to the conflation of morality and selfishness. ${ }^{9}$ Guided by selfish motivations, morality enters into rational calculations, giving them a longer but unspecified time frame. Moral behaviour is thus 'the name we give to the temporary sacrifices made in the interests of social co-operation, which is the chief means by which human wants and human life generally may be supplied' (Mises, 1922 , p. 167). The optimism Mises shows about the moral economy of the unhampered market is based on a diagnosis of its positive effects on human co-operation and on the apparent simplicity of the moral code required to sustain it, given its compatibility with human selfishness also nurtured by markets.

It is accompanied by a pessimistic outlook regarding the capacity of individuals to adhere to the ideology that is able to grasp these patterns and deliberately create the conditions for markets to flourish. Ultimately, Mises had to appeal to the 'moral courage' and benevolence of an intellectual elite. This is so because he identifies other competing ideologies that are able to cater to the 'instincts', instead of the reason, of the 'populace'; ideologies that partially reflect outdated and impossible to re-create (at least not without tremendous material costs) non-market patterns of economic integration (Mises, 1922). This diagnosis is shared by Hayek, although with some important differences of emphasis. As McCann (2004, p. 177) signals, 'Mises stresses the role of reason in the social order, while limiting the need for any structures which may have the effect of impending human action; Hayek de-emphasizes the role of reason and focuses attention on the role of moral rules'.

McCann's thesis can be better understood if one does not lose sight of the extent to which each author tackled the agency and structure question in their economic analysis, that is, the extent to which they avoided 'the extremes of voluntarism and determinism' and favoured 'an account of the structure-agency relationship that portrays

\footnotetext{
9 Mises (1949) uses the term 'selfishness' to indicate his general commitment to the idea that individuals are psychological egoists, that is, that whatever they do, is done because they are motivated to improve their own subjective satisfaction. In this context he argues: 'even an action directly aiming at the improvement of other people's conditions is selfish' because it generates satisfaction for the person in question (Mises, 1949, p. 243). Even if one accepts this fallacious thesis - from the idea that a person gets satisfaction from helping others, it is wrongly inferred that what actually motivates the individual is to get the satisfaction in question (Rachels, 2003) - there remains a distance between the general assumption of selfishness and his account of the actions to which individuals will tend to commit themselves when engaged in market interactions. This distance can only be bridged by the idea that when acting in markets, individuals' selfishness will translate into actions triggered by a narrower set of motivations basically aimed at the material improvement of their own situation. The predominance of these particular egoistical motivations ensures the smooth functioning of the market mechanism, according to Mises (Rodrigues, 2010).
} 


\section{J. Rodrigues}

socio-economic actors as socially embedded creatures whose (often creative) actions are both constrained and enabled by the social context in which they are situated' (Lewis, 2006, p. 376). Although on the one hand, Mises argued that it was not possible to analyse scientifically (at least within economics) the relations between institutions, human behaviour and its underlying motivations, on the other hand, he was convinced that capitalism had to be argued for at least partially in terms of these relations. If one couples this somewhat contradictory view with his defence of psychological egoism, of an extreme voluntaristic view about the possibilities of human action and of what Sciabarra (1995) calls a synoptic perspective of social life, according to which reason can devise the best possible institutional arrangements, one can better grasp the intellectual sources of Mises's extreme intellectual intransigency and Hayek's departures from it (Peck, 2008).

Indeed, Hayek's moral economy has as its starting point a double recognition: that 'man is as much a rule-following as a purpose-seeking one' (Hayek, 1973, p. 11) and that social theory 'starts from men whose whole nature and character is determined by their existence in society' (Hayek, 1948, p. 6). This is sufficient to distance Hayek's work from an atomistic view of socioeconomic reality (Sciabarra, 1995). Hayek focusses instead on the complex patterns of relations between human agency and social structures and develops an argument according to which the identification of these patterns - 'the kinds of circumstances which affect human action' (Hayek, 1967, p. 232) - is part of the proper aim of the social sciences. He adds one important epistemic caveat: one can only hope to arrive at an explanation of overall principles without ever expecting to gather the knowledge that might allow one to say that a particular individual action was the product of particular well-delimited and well-defined circumstances.

This is coherent with Hayek's socially and morally embedded view of the individual, who is much more dependent on moral and legal rules, within which a necessarily fallible individual might hope to learn how to behave rationally and virtuously. When compared with Mises, Hayek emphasises more the limits of human reason, the plasticity and diversity of human motivations and interests, and their relation with the diversity of institutions in which individuals interact. Indeed, within 'well-constructed institutions', the profit-making entrepreneur in the market realm, the impartial judge, the virtuous politician, who needs to exhibit 'probity, wisdom and judgment' (Hayek, 1979 , p. 112), the morally motivated intellectual or the citizen who understands the limits of politics and the perversities of collective action outside the market realm are all crucial to the survival of the Great Society (Rodrigues, 2013).

Hayek ends up converging with Mises in terms of the main conclusions of his moral economy: markets nurture social virtues; selfish motivations are adequate to the cash-nexus of the market, but have to be tempered by a progressively rarefied and adaptable moral code, which is valued as long as it is functional to the requirements of a market society. This evolving and adaptable moral code, the moral economy of neo-liberalism, goes against ingrained moral atavisms, which permanently try to re-create, through anti-market changes in the provision process, conditions for a communal life where people might have a host of shared ends. This 'socialistic' moral economy is inimical to Hayek's (1979) project and has to be deliberately discouraged. Reliant on a certain idea of the common good, albeit of a rather instrumental nature, Hayek's Great Society is also said to economise on morality and on 
the common ends individuals have to share: 'the advance of morals should lead to a reduction of specific obligations towards others', indeed, it 'requires', to an unspecified extent, 'the reduction of the range of duties we owe to all others' (Hayek, 1976, pp. 89-90).

Despite the distance from Mises's social rationalism, the recognition of the strength of moral atavisms (of which socialism is simply the most potent variety), partially conceived as a spontaneous outgrowth of the indispensable organisations that populate a market society, leads Hayek to increase the scope of rational analysis to be anchored in scientific knowledge and that of market engineering.

\section{Organising the ideological struggle and limiting democracy}

Mises and Hayek end up converging in the realm of ideas, antecedent and necessary to determine individuals' interests, and in the realm of institutional design, of a more piecemeal or more radical kind. While for Mises (1922, p. 540): 'The masses favour socialism because they trust the socialist propaganda of the intellectuals. The intellectuals not the masses are moulding public opinion'. According to Hayek (1948, p. 109): 'It is the beliefs which must spread if a free society is to be preserved, or restored, not what is practicable at the moment, which must be our concern. But, while we must emancipate ourselves from that servitude to current prejudices in which the politician is held, we must take a sane view of what persuasion and instruction are likely to achieve'.

The importance they gave to the struggle of ideas and public opinion is then at the root of the third priority on the agenda of the Mont Pelerin Society: to build a coherent discourse, not limited to economics, that could serve to go beyond a mere defensive exercise against 'totalitarianism' through the definition of a bold transformative agenda for capitalism.

Given the prominent place that ideas and their diffusion occupy in both Mises's and Hayek's work, the creation of and active participation in the Mont Pelerin Society was a move perfectly in tune with their intellectual diagnosis. This led to the creation of a host of other institutions connecting those who produce original knowledge of a scientific kind with the 'professional secondhand dealers in ideas', that is, those public intellectuals actively engaged in everyday public debate and in the formulation of public policy (Hayek, 1967). This is an even more coherent move if one bears in mind the adverse context to liberal ideas, after the war, which might explain the appeal to 'utopian' ideals and the effort to avoid any kind of naturalisation of socio-economic affairs and the denial of any kind of economic determinism in the trend of political developments (Hayek, 1944, 1967).

The tradition of Austrian economics is said to have adopted a non-cognitivist view of values, dismissing the viability of reaching an enduring agreement about them through reasoning and debate and arguing for a greater role for the market, as a 'conversationally inert institution', rather than the 'forum' (O’Neill, 1998, pp. 19-20). Nevertheless, both Mises and Hayek require the market to be underpinned by institutions and practices that are not conversationally inert. Moreover the conversation, given their elitist views, is rather one-sided because they assume a division between those whose role is to persuade and those who are to be persuaded. Indeed, most individuals have to be convinced to adopt 'common values' and to guide their behaviour by them. Hayek does not seem to 


\section{J. Rodrigues}

have many doubts about the effectiveness of this effort: 'That we can . . . influence people's conduct by education and example, rational persuasion, approval or disapproval, has never been seriously denied' (Hayek, 1960, p. 66). In this narrative, the market is constituted by a dense web of social rules of conduct, by organisations, that is, by nonmarket governance structures, mechanisms of co-ordination and common values, shaped by persuasion and opinion ensuring the continuing legitimacy of all these structures.

Mirowski's (2009, p. 432) depiction of the 'neoliberal thought collective' alludes to this:

Whereas leading neoliberals denied any possibility of mere mortals outcompeting the market as processors of highly dispersed knowledge, their own efforts succeeded in constructing and deploying an elaborate machinery designed to collect, create, debate, disseminate, and mobilize neoliberal ideas. By doing so, they greatly advanced the understanding of a modern reengineered division of intellectual labor with proper roles assigned to academic and other professionals, in what amounts to a new technology of persuasion.

In this context, Mirowski claims there is a 'double truth' at the heart of the intellectual work conducted by neo-liberals, with one truth for the 'masses' and one for those at the top of the social ladder and for corporate powers. Dimensions of this double truth includes the defence of the naturalisation of social order, expressed (amongst others) by the idea of the spontaneous order, hiding the clear constructivist line present in the unavoidable political engineering required to promote the agenda of commodification. It also includes the contrast between the Hayekian defense of the 'cosmos'-another name for 'a supposed spontaneous order that no one has intentionally designed or structured' (Mirowski, 2009, p. 425) — and the practical investment made in the creation of an 'elitist taxis': 'rationally constructed orders to achieve intentional ends' (Mirowski, 2009, p. 425).

These contradictions, which refer mostly to what Mirowski labels 'Hayek's playbook', deserve some critical scrutiny. Organisations such as the Mont Pelerin Society-and the same could be said for hospitals, courts, universities and so on-were always seen by Hayek as an integral part of an overall spontaneous order, which individuals and organisations could and must certainly influence and shape but whose evolution was bound to be more than the sum of their efforts and intentions (Hayek, 1948, 1960). The difference for Hayek was that this overall order could never be subsumed under an organisation, that is, societal ends could never be known and shared to the same degree that in an organisation. This general claim never led Hayek to doubt that the machinery of the state, an organisation, could and should be deliberately reconfigured so as to ensure that it uses the available knowledge to promote the expansion of markets and resist the advance of socialist ideals ${ }^{10}$. Hayek (1979, p. 152) was actually acutely aware of the need to 'construct an intellectual emergency equipment', since 'government is of necessity the product of intellectual design'. At the same time, this machinery was fundamental in determining the configuration of markets, as previously argued.

${ }^{10}$ This, as Gray (2002, p. 14) has argued, amounts to a recognition that the evolution of 'the unplanned workings of democratic institutions', channelling and giving political expression to what is considered (for example by institutionalists like Polanyi [1944]) to be a spontaneous movement demanding social protection to certain collective interests, can be profoundly inimical to the neo-liberal order and has to be deliberately countered. What is at stake is the problematic nature of the dichotomy - spontaneity versus constructionthat is sometimes mobilised by Hayek as part of the ideological arsenal to discredit his opponents and that became, together with the separation of the economy from the polity, one of neo-liberalism's most enduring myths, despite what can be garnered from the writings within this tradition on the practice of planning for certain forms of market-led institutional transformation. 
Rothschild's (2001, p. 152) remark about Hayek's elitist vision — 'the liberal is a scholar, a judge, a theorist who gives enlightened and respectful advice to the ruler' - could equally apply to Mises. The liberal, as a scholar, judge or public intellectual, not only advises politicians but, more important, elaborates the 'fundamental conceptions that constitute the framework of their thought and guide them in their action' (Hayek, 1960, p. 98). These elitist views are coherent with their scepticism towards 'unlimited democracy' (Hayek, 1979). The association between 'limited democracy' and the flourishing of the market is explicitly argued for by both Mises and Hayek: 'I doubt whether a functioning market has ever newly arisen under an unlimited democracy, and it seems likely that unlimited democracy will destroy it where it has grown up' (Hayek, 1979, p. 77). Mises and Hayek are very careful at distinguishing between liberal principles and the instrumental and very conditional adherence to what is now labelled as a Schumpeterian theory of democracy (Schumpeter, 1942), that is, a method allowing for the peaceful change of political elites that must be constrained in their policy options, amongst other things, by a constitution, which together with an open economy severely constrains the policy options of the majority, their capacity to inscribe socialist principles in the functioning of the economy ${ }^{11}$.

\section{Conclusion}

The analysis of the substantive ideological convergences between Mises and Hayek has hidden important intellectual divergences that began to manifest themselves in the socialist calculation debate. Contrary to what tends to happen in the ongoing debate between those who favour a homogenisation and those who favour a de-homogenisation of their intellectual contributions, to use Salerno's (1993) expression, this article has moved the focus away from the socialist calculation debate to a comparison of their views on the relation between the state and markets within capitalism, where the differences between Hayek and Mises are more intense and less scrutinised. They both acknowledge the role of a non-market sphere, mostly to the extent that it functionally contributes to guaranteeing the success of an ideological project based on the expansion of markets, but they diverge on the crucial issue of the complexity and the extension of the tasks to be attributed to it. This served to highlight the fact that even amongst two Austrian scholars participating in the collective reconstruction of economic liberalism, a positive program for change was far from settled and far from monolithic. In the area of moral economy, on the other hand, the substantive convergences were stronger, particularly the importance both gave to the role of ideas in the development of capitalism. This discussion brought to the fore that neo-liberalism is as an organised intellectual project marked by substantive internal discussions and disagreements that can only be captured if a more prominent role is given to the contributions of the individuals at stake.

\section{Bibliography}

Audier, S. 2008. Aux origines du néo-libéralisme: le colloque Walter Lippmann, Paris, Editions du Bord de l'eau

Block, W. 1996. Hayek's road to serfdom, fournal of Libertarian Studies, vol. 12, no. 2, 339-65

11 Mises (1927, p. 51), to whom Hayek constantly refers on the issue of the relation between liberalism and democracy, was convinced that regardless of the political regime, the socio-economic ideas prevailing in public opinion are the decisive factor in shaping policies (Caplan and Stringham, 2005). 


\section{J. Rodrigues}

Bowles, S. 1998. Endogenous preferences: the cultural consequences of markets and other economic institutions, Fournal of Economic Literature, vol. 36, no. 2, 75-111

Burczak, T. 2006. Socialism after Hayek, Ann Arbor, University of Michigan Press.

Caldwell, B. 2004. Hayek's Challenge-An Intellectual Biography of F. A. Hayek, Chicago, University of Chicago Press

Caplan, B. and Stringham, E. 2005. Mises, Bastiat, public opinion and public choice, Review of Political Economy, vol. 17, no. 1, 79-105

Eshelman, L. J. 1993. Ludwig von Mises on principle, Review of Austrian Economics, vol. 6, no. 2, $3-41$

Gamble, A. 1985. Capitalism or barbarism: the Austrian critique of socialism, Socialist Register, vol. $22,355-71$

Gray, J. 1998. Hayek on Liberty, London, Routledge

Gray, J. 2002. False Dawn-The Delusions of Global Capitalism,London, Granta

Greenwood, D. 2006. Commensurability and beyond: from Mises and Neurath to the future of the socialist calculation debate, Economy and Society, vol. 35, no. 1, 65-90

Greenwood, D. 2007. Planning and know-how: the relationship between knowledge and calculation in Hayek's case for markets, Review of Political Economy, vol. 19, no. 3, 419-33

Hartwell, R. 1995. A History of the Mont Pelerin Society, Indianapolis, Liberty Fund

Hayek, F. 1933 [1991]. The trend of economic thinking, in Bartley, W. W. and Kresge, S. (eds.), The Collected Works of F. A. Hayek, vol. 3, London, Routledge

Hayek, F. 1935. The nature and history of the problem, pp. 1-40 in Hayek, F. (ed.), Collectivist Economic Planning, London, Routledge and Kegan Paul

Hayek, F. 1937. Economics and knowledge, Economica, vol. 4, 33-54

Hayek, F. 1939 [1997]. Freedom and the economic system, in Caldwell, B. (ed.), The Collected Works of F. A. Hayek, volume 10, London, Routledge

Hayek, F. 1944 [2006]. The Road to Serfdom, London, Routledge

Hayek, F. 1948. Individualism and Economic Order, Chicago, University of Chicago Press

Hayek, F. 1960 [2006]. The Constitution of Liberty, London, Routledge

Hayek, F. 1967. Studies in Philosophy, Politics and Economics, London, Routledge

Hayek, F. 1973 [1982]. Law, Legislation and Liberty-Rules and Order, London, Routledge

Hayek, F. 1976 [1982]. Law, Legislation and Liberty-The Mirage of Social fustice, London, Routledge

Hayek, F. 1979 [1982]. Law, Legislation and Liberty-The Political Order of a Free People, London, Routledge

Hirschman, A. 1982. Rival interpretation of market society: civilizing, destructive or feeble?, fournal of Economic Literature, vol. 20, 1463-84

Ikeda, S. 1997. Dynamics of the Mixed Economy-Toward a Theory of Interventionism, London, Routledge

Keizer, W. 2000. The property rights basis of von Mises' critique of socialism and its relevance for the privatization of state enterprises in Eastern Europe, pp. 301-26 in Backhaus, J. G. (ed.), Modern Applications of Austrian Thought, London, Routledge

Kirzner, I. 2000. The Driving Force of the Market, London, Routledge

Lavoie, D. 1985. Rivalry and Central Planning: The Socialist Calculation Debate Reconsidered, Cambridge, Cambridge University Press

Lewis, P. 2006. Structure and agency in economic analysis: the case of Austrian economics and the material embeddedness of socio-economic life, pp. 364-85 in Davis, J. B., Marciano, A. and Runde, J. (eds.), The Elgar Companion to Economics and Philosophy, Cheltenham, Edward Elgar

Mack, E. 2006. Hayek on justice and the order of actions, pp. 259-86 in Feser, E. (ed.), The Cambridge Companion to Hayek, Cambridge, Cambridge University Press

Marquand, D. 2004. The Decline of the Public, Cambridge, Polity.

McCann, C. R., Jr. 2004. Individualism and Social Order-The Social Element in Liberal Thought, London, Routledge

Mirowski, P. 2009. Postface: defining neoliberalism, pp. 417-55 in Mirowski, P. and Plehwe, D. (eds.), The Road from Mont Pelerin - The Making of the Neoliberal Thought Collective, Cambridge, MA, Harvard University Press 
Mises, L. von 1920 [1935]. Economic calculation in the socialist commonwealth, pp. 87-130 in Hayek, F. (ed.) Collectivist Economic Planning, New York, Augustus M. Kelley

Mises, L. von 1922 [1951]. Socialism, New Haven, CT, Yale University Press

Mises, L. von 1927 [1985]. Liberalism, San Francisco, Cobden Press

Mises, L. von 1929 [1977]. A Critique of Interventionism, New Rochelle, NY, Arlington House

Mises, L. von 1944 [1938]. Bureaucracy, Cedar Falls, Center for Futures Education

Mises, L. von 1949. Human Action, London, William Hodge

Oliver, H. M., Jr. 1960. Mises on the harmony of interests, Ethics, vol. 70, no. 4, 282-90

O’Neill, J. 1998. The Market-Ethics, Knowledge and Politics, London, Routledge

Peck, J. 2008. Remaking laissez-faire, Progress in Human Geography, vol. 32, no. 3, 3-43

Plehwe, D. 2009. Introduction, pp. 1-42 in Mirowski, P. and Plehwe, D. (eds.), The Road from Mont Pelerin-The Making of the Neoliberal Thought Collective, Cambridge, MA, Harvard University Press

Polanyi, K. 1944 [2001]. The Great Transformation, Boston, Beacon Press

Popper, K. 1945 [2011]. The Open Society and its Enemies, London, Routledge

Rachels, J. 2003. The Elements of Moral Philosophy, New York, McGraw-Hill

Rodrigues, J. 2010. Are markets everywhere? Ludwig von Mises, Friedrich Hayek and Karl Polanyi, PhD thesis, University of Manchester

Rodrigues, J. 2013. Between rules and incentives: uncovering Hayek's moral economy, American fournal of Economics and Sociology, forthcoming

Rothschild, E. 2001. Economic Sentiments-Adam Smith, Condorcet and the Enlightenment, Cambridge, MA, Harvard University Press

Salerno, J. 1990. Ludwig von Mises as social rationalist, Review of Austrian Economics, vol. 4, $26-54$

Salerno, J. 1993. Mises and Hayek dehomogenized, Review of Austrian Economics, vol. 6, no. 2, $113-46$

Schumpeter, J. 1942 [1976]. Capitalism, Socialism and Democracy, London, Routledge

Sciabarra, C. 1995. Marx, Hayek and Utopia, Albany, State University of New York Press

Shearmur, J. 2006. Hayek's politics, pp. 148-70 in Feser, E. (ed.), The Cambridge Companion to Hayek, Cambridge, Cambridge University Press

Unger, R. M. 1998. Democracy Realized, London, Verso 